\title{
Performance and Carcass Production of Balinese Ducks Given Rumen Watse Based Biosupplement Rations
}

\author{
Gusti Ayu Mayani Kristina Dewi*, I Nyoman Sutarpa Sutama, I Wayan Wijana, and I Made Mudita \\ Faculty of Animal Husbandry, Udayana University, P. B. Sudirman, Denpasar, Bali, Telp. 0361235231 \\ *Corresponding author: elly_unud@yahoo.com
}

\begin{abstract}
A study aimed at studying the performance and production of Balinese duck carcasses that were given rations containing biosupplement-based waste of rumen content, conducted in the village of Peguyangan, Denpasar, Bali, for 3 months. Four biosupplements produced in this study were 1) $\mathrm{BR}_{0}=$ biosupplement with fermented rumen based waste without bacterial isolates, 2) $\mathrm{BR}_{1}=$ biosupplement with fermented rumen based waste with superior 1 cellulolytic bacteria inoculant $\left.\left(\mathrm{BR}_{3.5}\right), 3\right)$ $\mathrm{BR}_{2}=$ biosupplement with fermented rumen based waste with superior 2 cellulolytic bacterial inoculants $\left.\left(\mathrm{BR}_{3.3}\right), 4\right) \mathrm{BRmix}=$ biosupplement with fermented rumen based waste with combination of superior cellulolytic bacteria 1 and $2\left(\mathrm{BR}_{3.5}\right.$ and $\left.\mathrm{BR}_{3.3}\right)$, The study was carried out with Completely Randomized Sampling/CR Design with 5 treatments and 3 repetitions, in which each repetition consisted of 5 Balinese ducklings aged 2 weeks. The treatment given was to ducks given supplemented ration with $\mathrm{BR}_{0} ; \mathrm{BR}_{1} ; \mathrm{BR}_{2} ; \mathrm{BR}_{\text {mix }}$, respectively for the treatment of $\mathrm{R} 1 ; \mathrm{R} 2 ; \mathrm{R} 3$; and $\mathrm{R} 4$, as well as ducks that were given basal rations without supplementation (R5). The results showed that the performance of duck that received treatment of R2 was significantly better $(\mathrm{P}<0,05)$ than $\mathrm{R} 1, \mathrm{R} 3$, R4 and $\mathrm{R} 5$, while the carcass butching weight and fat weight were not significantly different $(\mathrm{P}>0,05)$. Based on the results obtained, it can be concluded; 1$)$ the performance of Balinese ducks receiving ration biosupplement of R2 is better compared to R1, R3, R4 and R5; 2) Meat production/ducks carcasses to the weight of butchery, carcass production, non-carcass parts and body fats are not significantly real between all treatments.
\end{abstract}

\section{Keywords: Biosupplements, Performance, Production, Carcass, Balinese Duck}

\section{INTRODUCTION}

Development of Balinese duck farms that have been conducted with integrated agricultural land needs to be improved and through the forage industry the utilization of waste, weeds of food crops is very important to note. Utilization of food crops waste and weeds such as banana stems, water hyacinth, apu leaf or other food crops/weeds into duck forages on the one hand will reduce the input production costs of up to $70 \%$ of a duck breeding business.

On the other hand, forage material from waste including weeds has various limitations such as unbalanced nutrient quality, high crude fiber content and its nutrient availability, minerals and low digestibility. Utilization of waste and weeds also has the potential to decrease livestock productivity since food crops and weeds are susceptible to decay and are vulnerable to contamination of various pathogenic microbes that can cause losses for farmers. Absolute forage technology applications should be applied in optimizing the utilization of food crops waste and weeds. Utilization of rumen waste as a bioinoculant product and supplementation have been proven to improve the quality and digestibility of in-vitro ration based on nonconventional waste [1], [2], [3].

Application of supplementation technology of poultry supplement product through the use of probiotic bacteria of superior cellulolytic origin from termites is very potential to be developed. The utilization of cellulolytic probiotic bacteria from termites is believed to improve the quality of the resulting biosupplement. Knowing termites that are wood-eating animals, they have various microbes (bacteria, protozoa, and fungi) as well as fiber degrading enzymes such as cellulose enzyme complexes (endo- $\beta$-D- 1.4-glucanase, exoglucanase and $\beta$-D-14-glucosidase). The results of [4] by isolating termites from 10 inoculants have been obtained the best of the isolates which were BR3.5 and BR3.3. This isolate is a gram positive (+) bacteria and has a morphology/shape of a coccus (BR3.5) and bacillus (BR3.3).

The use of isolate of superior cellulolytic probiotic bacteria from termite origin in the production of Balinese cattle rumen waste-based biosupplement has the potential to improve the quality and effectiveness of the resulting biosupplement. Based on the result of termite isolation research, therefore, research is done to investigate the influence probiotic biosupplement of termites on the performance and characteristic of Balinese duck.

\section{RESEARCH METHOD}

\section{Location and Time of Research}

The biosupplement production research was conducted at the Laboratorium of Nutrition and Livestock Forage, the faculty of Animal Husbandry of Udayana University. While the field research was conducted at farmers livestock cages in Peguyangan Kaja Village of Denpasar, Bali.

\section{Research Design}

The experiment was conducted through the use of isolate of superior cellulolytic probiotic bacteria 1 (BR 3.5) and 2 (BR 3.3) from termites as a result of first year research which is then formulated into 3 probiotic biosupplement based on rumen waste of Balinese cattle that will be utilized as a supplement for Balinese ducks. As a comparison, other biosupplements are produced without 
inoculation of superior cellulolytic probiotic bacteria from termite origins and livestock without being given probiotic biosupplement. The study was carried out with Completely Randomized Design/CRD with 5 treatment and 3 repetitions, in which each repetition consisted of 5 Balinese ducks aged 2 weeks. The treatments provided are:

$$
\begin{aligned}
& \mathrm{R} 1=\text { Duck given basal ration without supplemen- } \\
& \text { tation } \\
& \mathrm{R} 2=\text { Ducks fed with supplemented ration } \mathrm{BR}_{0} \\
& \mathrm{R} 3=\text { Ducks fed with supplemented ration } \mathrm{BR}_{1} \\
& \mathrm{R} 4=\text { Ducks fed with supplemented ration } \mathrm{BR}_{2} \\
& \mathrm{R} 5=\text { Ducks fed with supplemented ration } \mathrm{BR}_{\text {mix }}
\end{aligned}
$$

\section{Culture Isolate Cellulolytic Bacteria}

The stock of bacterial cellulolytic isolates from termites prior to use for the production of biosupplements was first grown on a cellulolytic liquid growth medium using a thioglicollate medium of $2.98 \mathrm{~g}$ per $100 \mathrm{ml}$ of medium with $0.2 \mathrm{~g} \mathrm{CMC}$ added as a substrate source. The isolate growth was carried out on liquid growth medium with a wavelength of $(\lambda) 650 \mathrm{~nm}$ with an absorbance of 0.5 aseptically on an anaerobic condition and then incubated for 5 days at Temperature of $39^{\circ}$ Celsius. Culture of bacterial isolates that have grown is then used in the production of biosuplement.

\section{Biosupplement and Its Production Technique}

Four biosupplements produced in this study were; 1) BR0 = biosupplement based on waste of fermented rumen content without bacterial isolates, 2) BR1 = biosupplement based on waste of fermented rumen content of superior cellulolytic bacteria inoculant 1 (BR3.5), 3) $\mathrm{BR} 2=$ biosupplement based on waste of fermented rumen content of superior cellulolytic bacterial inoculants 2 (BR3.3), 4) BRmix = biosupplement based on waste of fermented rumen content of superior cellulolytic bacteria 1 and 2 (BR3.5 and BR3.5).

The waste-based rumen biosupplement is produced with the ingredients composition is presented in Table 2 . This biosupplement is utilized as the basic ingredient of control biosupplement (BR0) as well as the probiotic biosupplement (BR1; BR2; BRmix). Biosupplement production is carried out by homogeneously mixing all constituents, while for the production of probiotic supplements; A homogenous biosupplement mixture of waste based rumen content was added as much as $0.5 \%$ culture of selected isolates according to the treatments $(0.5 \%$ culture of the superior isolate 1 for BR $1 ; 0.5 \%$ culture of the superior isolate 2 for BR2; and $0.25 \%+$ $0.25 \%$ each of superior isolate 1 and 2 for BRmix). It is then put into a tightly sealed plastic container and then incubated in an anaerobic incubator at $39^{\circ} \mathrm{C}$ for 1 week. After 1 week newly manufactured biosupplement products are dried with oven at $39-42^{\circ} \mathrm{C}$ until moisture content of the product is $25-20 \%$ (generally drying through oven is done for 2-3 days, depending on the water content of the previous material). After the completion of the drying proses, the biosupplement of waste-based rumen contents or probiotic biosupplements is ready to be used as a basal ration supplement with a $5 \%$ composition rate.

Basal Rations Based on Food Waste and Crop Weeds
The basal rations used in this study were waste-based rations and food crops weed prepared by following the NRC recommendations (1984) with the constituents presented in Table 1. Furthermore, the ration for this research is ready to be used as animal forages. Feeding provision of rations to livestock (Balinese Ducks) is done by ad libido.

TABLE 1.

\begin{tabular}{lc}
$\begin{array}{c}\text { COMPOSITION OF WASTE-BASED RUMEN } \\
\text { BIOSUPPLEMENT MATERIAL }\end{array}$ \\
\hline \multicolumn{1}{c}{ Constituents } & Composition (\% DM) \\
\hline Balinese cattle rumen & 20 \\
Molasses & 12 \\
Rice Barn & 20 \\
Corn Barn & 36 \\
Young Coconut & 4 \\
Gaplex & 3,2 \\
Rice straw & 4 \\
Kitchen Salt & 0,4 \\
Chalk & 0,32 \\
Pignox & 0,08 \\
\hline Total & 100 \\
\hline
\end{tabular}

Forage Based on Waste and Food Crops Weed

The basal rations used in this study were waste based and food crop weeds rations prepared by following the NRC recommendations (1984) with the ingredients composition presented in Table 2 . These basal rations will be used as control rations (R0) and supplemented rations (R1, R2, R3, and R4).

TABLE 2.

COMPOSITION INGREDIENTS TO CONSTRUCT BASAL RATIONS

\begin{tabular}{lc}
\hline Ingredients & Composition $(\% \mathrm{DM})$ \\
\hline Yellow Corn & 35 \\
Rice Barn & 15 \\
Corn Barn & 10 \\
Soy & 25 \\
Tapioca Flour & 6.5 \\
Molasses & 5 \\
Gamal Flour & 1 \\
Water hyacinth & 1 \\
Apu Leaves & 0.5 \\
Kitchen Salt & 0.4 \\
Pignok & 0,1 \\
\hline Total & 100 \\
\hline
\end{tabular}

\begin{tabular}{lc} 
Nutrient Contents * & \\
\hline Metabolized Energy & 2923,54 \\
Whole Protein & 16,156 \\
Whole Fiber & 5,07 \\
Whole Fat & 6,78 \\
Calcium/Ca & 0,96 \\
Phosfor/P & 0,69 \\
\hline
\end{tabular}

Description: * Standard requirement based on NRC (1984), with the nutrient content calculation of materials based on Hartadi (1990)

The rations supplemented with the biosupplements $\mathrm{BR} 0, \mathrm{BR} 1, \mathrm{BR} 2$, and BRmix (R1; R2; R3 and R4) were 
prepared by mixing a $95 \%$ homogeneous basal ration with $5 \%$ biosupplement (according to treatment). Afterwards the research ration is ready to be used as animal forage. Provision of rations to livestock (Balinese ducks) is done by ad libido and the level of ration consumption is calculated every day starting from morning (08.00 Middle Standard Time) until the next day (at 08.00 Middle Standard Time). Provision of rations was done by placing the ration in a plastic container placed in front of the duck's cage on each treatment unit.

\section{Balinese Ducks}

The ducks that will be used in this research are the Balinese male ducks aged 2 weeks and as many as 75 heads (5 treatments x 3 repitition, each @ 5 heads). Ducks are placed in research enclosures available in duck breeding areas of farmers in Peguyangan Kaja Village, Denpasar, Bali. The duck placement is done through a complete randomization technique by first weighing the body weight to get the initial homogeneous weight of the ducks (coefficient of variation $<5 \%$ ).

\section{Changes Observed}

Changes that are observed of livestock performance includes: body weight gain, consumption, and FCR/Feed Conversion Ratio, and the production of carcass.

\section{Data Analysis}

The data obtained were analyzed by variance analysis/Anova, if there was a significant difference $(\mathrm{P} \leq 0,05)$, the analysis was continued by the Duncans multiple range test [5].

\section{RESULTS AND DISCUSSION}

\section{Treatment Influence on Balinese Ducks Performance Age 2-8 Weeks}

The results showed that ducks treated with R2 (given feedstock supplemented with BR1 biosupplement which is of superior cellulolytic bacterial isolate 1 from termites)) were able to produce the highest body weight gain (475.76 gram / day) and with the lowest FCR $(5,13)$ showing a real difference $(\mathrm{P}<0.05)$ with the R5 feeding (basal ration without supplementation). However towards ration consumption, supplementation with waste-based biosupplement caused a decrease in ration consumption by the ducks and giving the R2 biosupplement showed the lowest consumption of ration (lowest consuming ducks) (Table 3).

The increased increase in body weight by utilizing a better ration (with lower FCR value) to livestock by giving supplemented ration with a waste-based biosupplement shows a good increase in forage digestion of the livestock. This is probably due to biosupplement that are produced contains a variety of fiber degradation microbes and microbial probiotics that able to improve digestibility and metabolism of the rations. In addition, by adding biosupplement in the ration it will be able to cover the various deficiencies/ weaknesses that exist in the wastebased rations and food crops weeds, therefore the supply of nutrients for livestock will be better and the resulting livestock productivity will increase.
The result of weight gain and the highest utilization of ration efficiency through treatment of R2 are the results of isolates used for the production of biosupplements of which are the best isolates of cellulolytic probiotic bacteria with the highest substrate degradation ability and with the highest cellulose enzyme activity [4].

The use of superior bacterial isolates with the best substrate degradation capability will certainly result in a good quality biosupplement and is able to be a probiotics that can improve the digestive process in the body of the livestock. The R4 treatment also utilizes the best isolate 1 combined with the best isolate 2 , but it did not produce the best possible biosupplement quality due to the interbacterial competition thus decreasing the ability of the bacteria. Wongwilaiwalin discloses the use of a bacterial consortium (more than 1 bacterium) the bacteria should be able to work synergistically. When the bacteria does not work synergistically, the enzyme product of from the first bacteria is not continued by the other bacterial enzyme activity, therefore the substrate degrading activity of the bacteria will be stopped [6].

The decrease of ration consumption in livestock that was given ration supplemented with waste-based rumen biosupplement (Table 3) does not illustrate a negative result. Thus considering the decrease in ration consumption does not describe the occurrence of nutritional deficiencies in livestock, but instead showed a higher increase in body weight, which reflects the wellness of livestock nutritional needs while nutrient metabolism is well and balanced. This occurs because the consumption of rations in poultry including ducks is strongly influenced by the nutrient needs, especially the energy for livestock [7]. When the need of nutrients, especially energy has been met, livestock will stop eating. In this study, the condition is clearly reflected in the provision of the biosupplement ration in BR0; BR1; BR2; BRmix (R1; R2; R3; R4) (Table 3).

\section{The Influence of Treatment Towards Duck Carcasses Aged 2-8 Weeks.}

The treatment had a significant effect $(\mathrm{P}>0,05)$ towards the carcasses, both on the percentage of carcass and non-carcass of Balinese ducks. The carcasses obtained from the treatment of R2 of $368.66 \mathrm{~g}$ was the highest and was significantly different with the treatment of R5, R1, $\mathrm{R} 3$ and R4 respectively of $3.71 \%, 7.05 \%, 6.33 \%$, and $6.33 \%$ which was much lower and significantly different $(\mathrm{P}<0.05)$ from $\mathrm{R} 2$.

The percentage of carcasses was significantly different $(\mathrm{P}<0.05)$ between $\mathrm{R} 2$ and $\mathrm{R} 3$ by $53 \%$ and $51.61 \%$. In the treatment of R1, R4 and R5 there were no statistically significant difference $(\mathrm{P}>0.05)$. The utilization of termite isolates as biosupplment was the best with the $\mathrm{R} 2$ compared with other treatment in R1, R4 and R5. This is due to R2 treatment which utilizes the best cellulolytic bacterial isolate 1 , which has the substrate degradation ability and has the highest enzyme activity; therefore the resulting biosuplement has best quality. The R4 treatment also utilizes the best isolate 1 combined with the best isolate 2, but did not produce the best biosupplement quality which was possibly due to the inter-bacterial competition thus decreasing the ability of the bacteria. 
Wongwilaiwalin discloses the use of a bacterial consortium (more than 1 bacterium), the bacteria should be able to work synergistically. When the bacteria do not work synergistically the enzyme product of the first bacteria is not continued by the activity of the other bacterial enzymes, therefore the bacterial activity in degrading the substrate will cease [6]. Overall, the use of waste-based rumen as a bioinoculant product and supplementation has proved to improve the quality and digestibility of Non-conventional waste-based rations so that the quality of carcass is higher and it decreased the weight of the duck non-carcasses [8], [3], [9]. Noncarcasses with the R1 treatment was not significantly different $(\mathrm{P}<0.05)$ with $\mathrm{R} 4$ and $\mathrm{R} 5$, whereas $\mathrm{R} 2$ and $\mathrm{R} 3$ showed a significant difference $(\mathrm{P}<0.05)$. The treatments were not significantly different $(\mathrm{P}>0.05)$ of the carcasses fat among treatments of R2, R3, R1, R4 and R5.

TABLE 3.

THE INFLUENCE OF TREATMENT TOWARDS THE PERFORMANCE OF DUCKS AGED 2-8 WEEKS

\begin{tabular}{|c|c|c|c|c|c|c|}
\hline \multirow{2}{*}{ Variable } & \multicolumn{6}{|c|}{ Treatment } \\
\hline & R1 & R2 & R3 & R4 & R5 & SEM \\
\hline Initial weight $(2 \mathrm{mg} / \mathrm{head})$ & $223,4^{\mathrm{a}}$ & $222,0^{\mathrm{a}}$ & $226.33^{a}$ & $224,8^{\mathrm{a}}$ & $222,47^{\mathrm{a}}$ & 0.489 \\
\hline End weight 8 weeks (g/heads) & $686,94^{\mathrm{b}}$ & $712,9^{\mathrm{a}}$ & $704,27^{\mathrm{ab}}$ & $698,27^{\mathrm{ab}}$ & $700,84^{\mathrm{ab}}$ & 5.236 \\
\hline Weight increase (g/day) & $463.74^{\mathrm{b}}$ & $475.76^{\mathrm{a}}$ & $462.79^{b}$ & $458,83^{c}$ & $446,33^{\mathrm{d}}$ & 0,709 \\
\hline Ration consumption (g/day/6weeks) & $2471,67^{\mathrm{ab}}$ & $2442,33^{b}$ & $2468,33^{\mathrm{ab}}$ & $2499,00^{\mathrm{ab}}$ & $2531.00^{\mathrm{a}}$ & 9.411 \\
\hline FCR & $5,33^{\mathrm{ab}}$ & $5,13^{\mathrm{b}}$ & $5,33^{\mathrm{ab}}$ & $5,45^{\mathrm{ab}}$ & $5.67^{\mathrm{a}}$ & 0.152 \\
\hline Butching weight & $687,67^{a}$ & $687,70^{\mathrm{a}}$ & $687,96^{\mathrm{a}}$ & $687,86^{\mathrm{a}}$ & $687,80^{\mathrm{a}}$ & 0.678 \\
\hline Carcasses & $343^{\mathrm{d}}$ & $368,66^{\mathrm{a}}$ & $355,00^{\mathrm{b}}$ & $342,67^{d}$ & $345,33^{\mathrm{c}}$ & 0.574 \\
\hline Carcasses \% & $49,87^{\mathrm{c}}$ & $53,60^{\mathrm{a}}$ & $51,61^{\mathrm{b}}$ & $49,78^{\mathrm{c}}$ & $50,20^{\mathrm{c}}$ & 0.420 \\
\hline Fat (g/head) & $0,39^{\mathrm{a}}$ & $0,36^{\mathrm{a}}$ & $0,38^{\mathrm{a}}$ & $0,43^{\mathrm{a}}$ & $0,39^{\mathrm{a}}$ & 0.017 \\
\hline Non-carcasses & $344,67^{\mathrm{ab}}$ & $319,09^{\mathrm{d}}$ & $332,97^{\mathrm{c}}$ & $345,27^{\mathrm{a}}$ & $342,42^{\mathrm{b}}$ & 0.725 \\
\hline
\end{tabular}

Note: R1= Rumen Waste-Based Biosupplemented Ration; R2= Biosupplemented Ration with BR2; R3= Biosupplemented Ration with R2; R4= Biosupplemented Ration with BR1-BR2; and R5 = Basal Ration.

\section{CONCLUSION AND SUGGESTION}

\section{Conclusion}

Based on the result of the research, it can be concluded that the $\mathrm{R} 2$ biosupplement ration of BR1 termite isolate supplementation has a significant effect on the performance and does not affect the carcass production and decreases the carcasses fat of Balinese ducks.

Suggestions

Based on the research data that has been obtained, it can be recommended to use the $\mathrm{RBiO} 1$ ration.

\section{ACKNOWLEDGEMENT}

The author would like to thank the Minister of Education and Culture of Indonesia, through the Director of Research and Community Services and the Rector of Udayana University through LPPM UNUD for the fund given by the contract of PNBP.No.311-180 / UN14.2 / PNL.01.03.001 / 2015 .

\section{REFERENCES}

[1] Mudita, I M., I W. Wirawan, AA. P.P. Wibawa. 2010. Suplementasi Bio-Multi Nutrien yang Diproduksi Dari Cairan Rumen untuk Meningkatkan Kualitas Silase Ransum Berbasis Bahan Lokal Asal Limbah. Laporan Penelitian Dosen Muda Unud, Denpasar.

[2] Mudita, I M., I W. Wirawan, A. A. P. P. Wibawa, I G. N. Kayana. 2012. Penggunaan Cairan Rumen dan Rayap dalam Produksi Bioinokulan Alternatif serta Pemanfaatannya dalam Pengembangan Peternakan Sapi Bali Kompetitif dan Sustainable. Laporan Penelitian Hibah Unggulan Perguruan Tinggi. Universitas Udayana, Denpasar.
[3] Dewi, G. A. M.K, I W. Wijana, I W. Siti, I M. Mudita. 2013. Optimalisasi Pemanfaatan Limbah Gulma Tanaman Pangan Dalam Usaha Peternakan Itik Bali melalui Produksi Biosuplemen Berprobiotik Berbasis Limbah Isi Rumen. Laporan Penelitian Unggulan Udayana 2013.

[4] Dewi G.A.M.K., I N.S. Sutama, I.W.Mudita, I W.Wijana. 2014. Kemampuan degradasi senyawa selulosa dari bakteri probiotik selulolitik yang diisolasi dari rayap. Prosiding Seminar Nasional Sainsdan Teknologi, Unud, 18-19 September 2014.

[5] Sastrosupadi, A.. 2000. Rancangan Percobaan Praktis Bidang pertanian. Edisi Revisi. Penerbit Kanisius, Yogyakarta

[6] Wongwilaiwalin, S., U. Rattanachomsri, T. Laothanachareon, L. Eurwilaichirt, Y. Igarashi, V. Champreda. 2010. Analysis of a thermophilic lignocellulose degrading microbial consortium and multi-species lignocellulolytic enzyme system. Enzyme and Microbial, Technology Journal 47: 283290.

[7] Sanjaya, L. 1995. Pengaruh penggunaan isi rumen sapi terhadap PBB, konsumsi dan konversi pada ayam pedaging strain loghman. Skripsi. Fakultas Peternakan Universitas Muhammadiyah Malang.

[8] Mulyono, R. Murwani, F. Wahyono. 2009. Kajian penggunaan probiotik Sacckaromyces cerevisiae sebagai alternatif aditif antibiotik terhadap kegunaan protein dan energi pada ayam broiler. Jurnal of The Indonesian Tropical Animal Agriculture 32(2): 145151.

[9] Kompiang, I P. 2009. Pemanfaatan microorganisme sebagai probiotik untuk meningkatkan produksi ternak unggas di Indonesia. Jurnal Pengembangan Inovasi Pertanian 2(3): 177-191. 